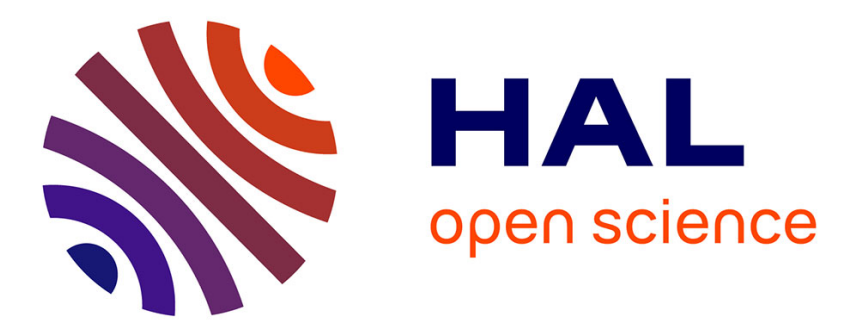

\title{
Policy assessment of an EU wide flat area CAP payments system
}

Emil Erjavec, Frederic Chantreuil, Kevin Hanrahan, Trevor Donnellan, Guna Salputra, Maja Kožar, Myna van Leeuwen

\section{> To cite this version:}

Emil Erjavec, Frederic Chantreuil, Kevin Hanrahan, Trevor Donnellan, Guna Salputra, et al.. Policy assessment of an EU wide flat area CAP payments system. Economic Modelling, 2011, 28 (4), pp.15501558. 10.1016/j.econmod.2011.02.007 . hal-01462582

\section{HAL Id: hal-01462582 \\ https://hal.science/hal-01462582}

Submitted on 29 May 2020

HAL is a multi-disciplinary open access archive for the deposit and dissemination of scientific research documents, whether they are published or not. The documents may come from teaching and research institutions in France or abroad, or from public or private research centers.
L'archive ouverte pluridisciplinaire HAL, est destinée au dépôt et à la diffusion de documents scientifiques de niveau recherche, publiés ou non, émanant des établissements d'enseignement et de recherche français ou étrangers, des laboratoires publics ou privés. 
Post-print

Published as: Erjavec, E. ; Chantreuil, F. ; Hanrahan, K. ; Donnellan, T. ; Salputra, G. ; Kožar, M. ; van Leeuwen, M. Policy assessment of an EU wide flat area CAP payments system.

Economic Modelling. 2011, 28 (4) : 1550-1558

Doi : http://dx.doi.org/10.1016/j.econmod.2011.02.007

Copyright : Elsevier

\title{
Policy assessment of an EU wide flat area CAP payments system
}

\author{
Emil Erjavec ${ }^{1}$, Frédéric Chantreuil ${ }^{2}$, Kevin Hanrahan $^{3}$, \\ Trevor Donnellan ${ }^{3}$, Guna Salputra ${ }^{4}$, Maja Kožar ${ }^{1}$, Myrna van Leeuwen ${ }^{5}$ \\ ${ }^{1}$ University of Ljubljana, Biotechnical faculty, Groblje 3, Domzale, Slovenia; emil.erjavec@bf.uni-lj.si; maja.kozar@bf.uni-lj.si \\ ${ }^{2}$ Centre of Agricultural Economics, INRA-ESR, 4 allée Adolphe Bobierre, CS 61103, 35011 Rennes cedex, France; \\ frederic.chantreuil@rennes.inra.fr \\ ${ }^{3}$ Rural Economy Research Centre (RERC), Teagasc, Athenry, Co. Galway, Ireland; Trevor.Donnellan@teagasc.ie; \\ Kevin.Hanrahan@teagasc.ie \\ ${ }^{4}$ Latvian State Institute of Agrarian Economics (LSIAE), 14 Struktoru St, Riga, Latvia; guna@1vaei.lv \\ ${ }^{5}$ LEI, Alexanderveld 52585 DB The Hague The Netherlands; Myrna.vanleeuwen@wur.nl
}

\begin{abstract}
While the evolution of the Common Agricultural Policy (CAP) until 2013 is clear, European Union (EU) budgetary pressures and the perceived unfairness of the distribution of CAP support across Member States has lead to uncertainty over the design of the CAP post 2013. One comprehensive reform option being considered is the implementation of an EU wide flat area payment (EUWFAP) system and a reduction of the total budget available for direct payments. It is hypothesized that the implementation of this policy proposal would lead to significant changes in the distribution of the EU budget and to the redistribution of agricultural production between the Member States, which could hinder the implementation of the proposal. This paper evaluates the rationality of the EUWFAP, based on the analysis of its budgetary and market impacts. Using the AGMEMOD 2020 combined model, the introduction of the EUWFAP in 2013 is compared with a baseline continuation of the current policy. Results suggest that there would be minor negative impacts on the agricultural production at the EU level, but that more substantial impact for some commodities, most notably beef, could occur in the individual EU Member States. An important outcome of such a policy reform would be a substantial change in the budget allocation between Member States, which could help mitigate the budgetary tensions between the Member States.
\end{abstract}

JEL Code: Q18, Q11, C53, N54

Keywords: CAP reform, EU budget reform, agricultural markets, partial equilibrium models

Corresponding author: Emil Erjavec, University of Ljubljana, Biotechnical faculty, Groblje 3, 1230 Domzale, Slovenia;

e-mail: emil.erjavec@bf.uni-lj.si; tel.0038617217852 


\title{
Policy assessment of an EU wide flat area CAP payments system
}

\begin{abstract}
While the evolution of the Common Agricultural Policy (CAP) until 2013 is clear, European Union (EU) budgetary pressures and the perceived unfairness of the distribution of CAP support across Member States has lead to uncertainty over the design of the CAP post 2013. One comprehensive reform option being considered is the implementation of an EU wide flat area payment (EUWFAP) system and a reduction of the total budget available for direct payments. It is hypothesized that the implementation of this policy proposal would lead to significant changes in the distribution of the EU budget and to the redistribution of agricultural production between the Member States, which could hinder the implementation of the proposal. This paper evaluates the rationality of the EUWFAP, based on the analysis of its budgetary and market impacts. Using the AGMEMOD 2020 combined model, the introduction of the EUWFAP in 2013 is compared with a baseline continuation of the current policy. Results suggest that there would be minor negative impacts on the agricultural production at the EU level, but that more substantial impact for some commodities, most notably beef, could occur in the individual EU Member States. An important outcome of such a policy reform would be a substantial change in the budget allocation between Member States, which could help mitigate the budgetary tensions between the Member States.
\end{abstract}

JEL Code: Q18, Q11, C53, N54

Keywords: CAP Reform, EU Budget Reform, Agricultural Markets, Partial Equilibrium Models

\section{Introduction}

Besides cohesion policy, agricultural policy is the only significant budgetary policy of the European Union (EU), which is determined entirely at the Community level and predominantly funded from the EU budget. The primacy of the Common Agricultural Policy (CAP) stems from the desire, after World War II, for greater economic integration of Europe and a related requirement to establish food security in post-war Europe (Tracy, 1997; Ritson and Harvey, 1997). Since its origins the CAP has been moulded through successive reforms resulting from constant internal and external pressures (Yrjölä and Kola, 2001; Garzon 2006; Swinnen, 2008) such as domestic budgetary problems and international trade negotiation obligations (Swinnen, 2008; Cunha and Swinbank, 2009).

Since the 1992 MacSharry reform, there have been reductions in intervention prices, export subsidies and import protection, as well as the abolition of certain supply management measures. The 2003 Fischler reform and the Health Check revision of the CAP (Council Regulation 1782/03, 2003; Council Regulation 73/09, 2009) changed the basis for direct payments. The main aim of these reforms was to strengthen the EU position in the ongoing World Trade Organisation (WTO) negotiations (WTO, 2008), however the introduction of historical payment schemes has largely preserved the scope and distribution of funds across the Member States and between farmers within Member States.

The future of the CAP will largely depend on the post 2013 EU budget debate, in on the conclusiobs reached in relation to the size, type and justification of the direct payments to EU farmers. Any prediction of the long-term changes of the CAP is speculative, as such changes will largely depend on the division of power between the reformist and more conservative Member States (Garzon, 2006; Swinnen, 2008) and possible external factors such as developments in the WTO negotiations (Daugbjerg and Swinbank, 2007).

Contributions by Member States to the post 2013 EU budget are unlikely to increase significantly, but the pressure from the net contributing Member States to reduce CAP spending is set to increase (Begg, 2005; Begg and Heinemann, 2006; Begg et al., 2008; ECORYS, 2008). There is also a realistic possibility of a re-nationalisation of Pillar I of the CAP, i.e. where all Member States would be required to co-finance supports from national funds (Grybauskaité, 2008). 
Pressures for the greater uniformity in the level of direct payments across Member States will increase. In addition, average direct payment amounts will probably decrease due to the pressures from some Member States for their abolition, since expenditure on direct payments accounts for two thirds of the CAP budget. The continuation of direct payments may hinge on reducing their redistributive nature (Begg and Heinemann, 2006; Cipriani, 2007) and on finding a new rationale for their existence, such as ensuring public goods provision by agriculture (OECD, 2003; Yrjölä and Kola, 2004; Begg et al., 2008; Bureau and Mahé, 2008).

Agricultural interest groups and certain policy makers on the other hand stress the importance of current system of direct payments in preserving an adequate level of European agricultural production and argue that the abolishment or comprehensive reduction of payments would have negative impacts on the production level as well as on agricultural foreign trade. However, several recent studies (e.g. Nowicki et al., 2009; Vrolijk et al., 2010) suggest that the impacts of the abolishment of direct payments would not be as detrimental to EU27 agricultural production as argued by the above mentioned stakeholders. However, the they find that the negative impacts of direct payment abolition could be more significant at the level of individual Member States, regions, commodities or types of farms.

In this paper, one possible post 2013 CAP reform scenario is outlined and its impact on the EU budget and agricultural markets is analysed using the AGMEMOD 2020 combined model of European agriculture (AGMEMOD Partnership, 2008). The post 2013 CAP reform scenario analysed, the introduction of an EU wide flat area payment (EUWFAP), reflects some of the content of recent public debates concerning the long term future of the CAP (Hervieu 2010; Matthews 2010). The main hypothesis is that the implementation of such a reform scenario could lead to significant changes in the budgetary distribution of direct payments between Member States, whereas the impacts on EU27 agricultural commodity markets, while negative, would be relatively minor.

The paper is structured as follows. Section 2 outlines the perceived difficulties with the provision of CAP Pillar I support and sets out some proposals for alternative farm income support mechanisms. It also provides a discussion of the EU budget review. Section 3 discusses the structure of the model used for the analysis with particular emphasis on the incorporation of policy measures in the model and goes on to set out a CAP reform scenario for evaluation. Section 4 details the results of the analysis and Section 5 includes a discussion of the results and some conclusions.

\section{EU agriculture and budget}

\subsection{CAP Pillar I direct payments}

Since the Fischler Reform of 2003, Pillar I of the CAP comprises of a combination of decoupled direct payments, price supports and coupled payments (CAP Monitor, 2009). Financially and politically, direct payments are the most important element of the CAP. A national envelope is defined for each Member State and these envelopes in effect represent historical rights to funds for direct payments. These funds are then distributed in each Member State according to the relevant implementation model of the single farm payment chosen (Council Regulation 1782/03, 2003; Council Regulation 73/09, 2009).

Conservative Member States, like France, Ireland and Spain, who in the past have generally been opposed to CAP reform, largely use the historical model of the single farm payment. Under the historical model the individual producer's payments are based on payment rights set by reference to the level of production and payments in the historical reference period. In contrast to this basic scheme, England, Wales and Germany are gradually adopting the so called regional model, whereby a uniform regional payment replaces the historical payments. Several Member States, including Finland, Denmark and Slovenia, use a hybrid model, which combines the elements of the historical and regional direct payments models. While the 2003 CAP reform introduced decoupling of direct payments, it also allowed continuation of certain coupled payments and some Member States, such as France and Spain, have availed of this possibility. The new Member States (EU12), except Slovenia and Malta, use uniform hectarage (per hectare) payments for agricultural land (simplified area payment scheme or SAPS) which is similar to the regional model, but without the system of paying 
rights for the producer. The 2008 Health Check revision of CAP encourages, but does not oblige, Member States to harmonise policy across the Union. Under Health Check Member States may change their policy towards the regional single payment model (equal hectarage payment for all the producers in a region, defined as no smaller than 3 million hectares).

The proposition, that decoupled (lump sum) payments do not have production, market and redistributive effects (Conforti, 2005) holds in the case of production neutrality and when markets are complete. However, Key and Roberts (2008) list numerous studies (Hennessy, 1998; Chau and de Gorter, 2000; Burfisher and Hopkins, 2003; Roe et al., 2003) that establish that with imperfect labour, credit or insurance markets, decoupled payments can have production effects. These effects tend on average to be minor, but could have significant consequences for the structure of individual agricultural holdings (Key and Roberts, 2008).

Table 1 shows indicative estimates of average direct payments per hectare of utilised agricultural area across the Member States. There are large disparities in terms of average payments per hectare among the Member States. On average, the hectarage payment is the highest in Greece (544 EUR/ha), followed by Malta (494 EUR/ha), whereas the payments are on average lowest in the Baltic States (Latvia $83 \mathrm{EUR} / \mathrm{ha}$ ) and in Romania (92 EUR/ha). These disparities have become a serious political issue between the Member States and will significantly influence the nature of the debate on the CAP post 2013.

Table 1: Average CAP Pillar I direct payments per hectare of utilised agricultural area by EU Member States

\begin{tabular}{|c|c|c|}
\hline Member State & $\begin{array}{c}\text { National envelope for } \\
\text { CAP Pillar I direct payments } \\
\text { in } 2013^{*} \\
(\text { Mio. EUR })\end{array}$ & $\begin{array}{c}\text { Average CAP Pillar I } \\
\text { direct payments per hectare of } \\
\text { utilized agricultural area } \\
(E U R / h a)\end{array}$ \\
\hline \multicolumn{3}{|l|}{ EU15: } \\
\hline Austria & 752 & 236 \\
\hline Belgium & 615 & 447 \\
\hline Denmark & 1,049 & 394 \\
\hline Finland & 571 & 249 \\
\hline France & 8,521 & 310 \\
\hline Germany & 5,853 & 346 \\
\hline Greece & 2,217 & 544 \\
\hline Ireland & 1,341 & 324 \\
\hline Italy & 4,370 & 343 \\
\hline Luxembourg & 37 & 283 \\
\hline Netherlands & 898 & 469 \\
\hline Portugal & 606 & 174 \\
\hline Spain & 5,139 & 206 \\
\hline Sweden & 771 & 247 \\
\hline United Kingdom & 3,988 & 247 \\
\hline \multicolumn{3}{|l|}{ EU12: } \\
\hline Bulgaria & 580 & 190 \\
\hline Cyprus & 53 & 366 \\
\hline Czech Republic & 909 & 258 \\
\hline Estonia & 101 & 112 \\
\hline Hungary & 1,319 & 312 \\
\hline Latvia & 146 & 83 \\
\hline Lithuania & 380 & 143 \\
\hline Malta & 5 & 494 \\
\hline Poland & 3,045 & 197 \\
\hline Romania & 1,264 & 92 \\
\hline Slovakia & 388 & 200 \\
\hline Slovenia & 144 & 295 \\
\hline
\end{tabular}

* 2016 for Bulgaria and Romania.

Source: Adapted from Baldock et al. (2010): Table 1.3. (pg. 45), Table 1.4. (pg. 46).

New EU Member States, in particular Poland, Latvia and Estonia, have highlighted the disparities in the level of direct payments per hectare and have made requests for their equalisation (Seeder, 2008; 
CAP POST-2013 ..., 2010) in the direction of EUWFAP. The equalization of payment levels across Member States so as to ensure a fairer and more equitable agricultural policy in the EU has become one of the main topics of the post 2013 CAP reform (The Common Agricultural ..., 2010).

Justifying the CAP is central to forming a sustainable long-term perspective for agricultural support in the EU. It has been argued (e.g. Bureau and Mahé; Frandsen, 2008; IEEP, 2010) that agricultural policy can be justified by its rôle in the provision of public goods and, that accordingly, the name and stated objectives of the CAP should be changed (Buckwell, 2007; Swinnen, 2008; Begg et al., 2008; Bureau and Mahé, 2008). Pillar I CAP payments for environmentally and animal welfare friendly agriculture and supports to agriculture in less favoured areas could, together with more targeted payments under the Pillar I (such as EUWFAP), form a system of payments for various public goods related to agriculture, as proposed by Bureau and Mahé (2008) and Baldock et al. (2010). They advocate that the current single farm payment system should be replaced with a contractual payment system, under which direct payments would be paid in return for the provision of adequate levels of public goods and services.

However, the issue of remuneration for public goods provided by European agriculture is not straightforward. The costs of supplying non-commodity outputs through agriculture differ across the EU Member States and regions, as does the consumer demand and willingness to pay for these goods. Thus, differentiated regional payments have gained more political support than the EUWFAP (The CAP towards ..., 2010; CAP POST-2013 ..., 2010).

The analysed flat area payment system (EUWFAP) is basically more equitable than the current direct payments system in terms of payment disparities between different Member States and is also considerably more straightforward in design. However, it remains controversial in the sense that it could lead to a politically unacceptable redistribution of budgetary envelopes and direct payments, even an EU-wide flat rate per eligible hectare or a regional flat area payments system in all Member States could have a large impact on agricultural land values (Kilian et al., 2008) and could lead to structural changes with adverse implications for the provision of public goods. The transition from the current direct payment models towards an EUWFAP could be facilitated by applying the additional "objective" criteria (e.g. Copenhagen Conference discusses ..., 2010), such as correcting for purchasing power parity, fixed inputs or agricultural production.

\subsection{Budgetary dimension of CAP}

Substantial redesign of the direct payment system requires simultaneous consideration of the broader context of EU budget reform debate. There are two main perspectives on the possible direction of EU budget reform. Academics and policy makers see the post 2013 budgetary planning process, together with CAP reform, as a historical opportunity to conduct, for the first time since the 1988 EU budget reform, a thorough overhaul of the EU budget and undertake the necessary changes that will allow the EU to effectively face the new challenges and changing environment (Begg and Heinemann, 2006; Cipriani, 2007; ECORYS, 2008; Begg et al., 2008). The insecurity created by the current global economic crisis further fuels expectations regarding the EU budget reform.

It is worth recalling that the EU budget is relatively small in size, accounting for approximately $1 \%$ of EU GDP and just over 2\% of total EU public expenditure (ECORYS, 2008; Begg et al., 2008). In the last two decades, around $80 \%$ of all EU budgetary expenditure was on agricultural and cohesion policies, whereas the remaining amount, viewed as paradoxically insufficient by the reformists (see Grochowska and Kosior, 2008; Begg et al., 2008), was spent on the ambitious strategic goals of the EU as set out in the Lisbon and EU 2020 Strategies, mainly policies aimed at increasing the competitiveness of the EU (Begg, 2005; ECORYS, 2008; Begg et al., 2008).

Any future EU budget reform will have to address the two key principles of the EU budget: the subsidiarity principle, i.e. what should be financed at the EU level or at the level of the Member State, and the proportionality principle, i.e. the total size of the EU budget. In line with the EU Treaties, the EU budget is a subsidiary instrument of European public finances, whose added value is directly related to the concept of the "European public good", i.e. the public good that justifies financial 
intervention at the EU level. According to Begg et al. (2008) the EU Single Market is the basic (integrative) European public good.

The ECORYS study (ECORYS, 2008) argues that path dependency appears to be the main argument for the current existence of CAP direct payments and market interventions. Begg et al. (2008) see the path-dependent character of CAP expenditure as a part of the "side-payments" logic necessary to facilitate the conclusion of the political deals that lie at the heart of the process of EU integration, a logic that has enjoyed great political support in the past. If the EU wants to change the structure of its budget, moving away from predominantly redistribution oriented towards more allocation (target) oriented financing of European policies, all the existing budgetary policies, in particular the CAP, will have to be reviewed and reformed.

Table 2: Expected inflows from the CAP and the CAP net financial position in 2013 by Member States

\begin{tabular}{lcc}
\hline Member State & $\begin{array}{c}\text { CAP inflows } \\
\text { (CAP Pillar I and II) } \\
\text { (Mio. EUR, 2004 prices) }\end{array}$ & $\begin{array}{c}\text { CAP net } \\
\text { financial position* }\end{array}$ \\
\hline Poland & 3,808 & 2,642 \\
Romania & 2,294 & 1,907 \\
Ireland & 1,779 & 1,120 \\
Hungary & 1,484 & 982 \\
Greece & 1,669 & 804 \\
Spain & 4,797 & 690 \\
Bulgaria & 785 & 651 \\
Czech Republic & 1,047 & 538 \\
France & 8,648 & 532 \\
Lithuania & 523 & 405 \\
Portugal & 1,036 & 377 \\
Slovak Republic & 562 & 353 \\
Denmark & 1,169 & 184 \\
Latvia & 245 & 178 \\
Estonia & 198 & 142 \\
Slovenia & 219 & 61 \\
Finland & 743 & 4 \\
Malta & 13 & -14 \\
Cyprus & 53 & -24 \\
Austria & 1,038 & -26 \\
Luxembourg & 43 & -73 \\
Sweden & 839 & -345 \\
Netherlands & 1,612 & -473 \\
Belgium & 993 & -839 \\
Italy & 4,119 & $-2,505$ \\
United Kingdom & 4,152 & $-2,685$ \\
Germany & 6,276 & $-3,430$ \\
\hline
\end{tabular}

* Net financial position for agriculture is calculated as a difference between estimated CAP inflows for CAP Pillar I and II and expected total payments in EU total budget (British rebate included), according to the agreed financial perspective for the period 2007- 2013.

Source: own calculations.

The path dependent character of the CAP and EU budget is also evident from the fact that in the past the EU budget has changed relatively little in terms of its emphasis on agriculture. Table 2 shows the average annual inflows and net budgetary position of EU Member States regarding the CAP. The disparities between Member States can be explained by the disparities in the scope of resources, intensity and productivity of agriculture, as well as by the level of funds available for rural development policy.

Reflecting the pressures within the WTO Doha round (WTO, 2008), the European Commission has indicated that it will agree to further liberalisation of international trade by committing to a removal of export subsidies by 2013 and demonstrating a willingness to reduce border protection. Thus it can be expected that beyond 2012 market intervention will be less prevalent. We can therefore expect a substantial reduction in EU funding in this area, but not its complete removal.

Regarding rural development policy the main question is whether a policy which was developed for more affluent Member States as a supplement to the CAP Pillar I and aimed at balancing their net contributor positions can actually be regarded as a common European policy, especially since there is 
another development policy based on a territorial approach, EU cohesion policy, also in existence. In Member States with serious development needs, particularly some new Member States, rural development policy can be in grave conflict (content- and implementation-wise) with cohesion (regional) policy, which requires more coherent action at the national and European levels. However, it is unlikely that rural development policy will be abolished or merged with cohesion policy.

Ultimately, the future size and structure of the agricultural budget will be determined largely by decisions concerning the direct payments system. From the literature and public debate (Baldock et al., 2010; Hervieu, 2010; Matthews, 2010) the impending reform must address the challenges of i) finding a new justification for the continuation of the CAP, ii) designing a new direct payments policy that is linked to the justification for policy and iii) delivering the new CAP with reduced budgetary resources. The most probable direction of further reforms appears to be the introduction of i) a basic EU wide flat area payment or other more regionally uniform types of payments (to reflect disparities in economic and natural conditions for agricultural production throughout EU) and ii) some additional payments for remunerating public goods provided by the European agriculture, thus making the CAP more equitable, targeted and efficient (The CAP towards ..., 2010; CAP POST-2013 .., 2010).

Reductions in Pillar I CAP funding by the EU could also be achieved if these payments were to become co-financed from national budgets, this direction is seen as the logical next step if the CAP is to target the provision of public goods more efficiently (OECD, 2003; Yrjölä and Kola, 2004; Begg et al., 2008). Different levels of co-financing could more efficiently address the problem of disparities in the prices of public goods provided by agriculture throughout the EU.

\section{The Methodology}

\subsection{AGMEMOD partial equilibrium modelling approach}

The market impacts of the proposed reform scenario is estimated with the AGMEMOD 2020 combined model (AGMEMOD Partnership, 2008). The AGMEMOD 2020 combined model is an econometric, dynamic, multi-product partial equilibrium model in which a bottom-up approach is used (AGMEMOD Partnership, 2008). Based on a common model template, individual country models reflecting the specific situation of the agriculture in the individual Member States have been developed during the course of different AGMEMOD 2020 projects (Salamon et al., 2008). The approach allows for the inherent heterogeneity of EU agriculture to be captured, while simultaneously maintaining analytical consistency across all the individual country models. The incorporation of CAP instruments in a harmonized fashion in each of the country models allows the AGMEMOD 2020 combined model to analyse important policy relevant questions and the impact of possible policy changes, at the individual Member State and aggregate EU levels in a consistent and transparent manner.

The AGMEMOD country model for a given Member State consists of different supply and market modules for those commodities that represent the majority of the agricultural output of the Member State concerned. For each commodity in a given Member State, agricultural production as well as supply, demand, trade, stocks and domestic prices are derived by econometrically estimated equations. One element of the supply and demand balance, for each commodity modelled, is derived as a closure variable. Within this combined model environment all EU prices, as well as all elements of agricultural commodity supply and demand in each Member State, are modelled endogenously. As the AGMEMOD 2020 combined model does not represent a closed economy, key price equations are used to take into account the impact of the developments in non-EU marke0ts (the Rest of the World) on EU agriculture. To solve the combined modelling system in prices, the supply and utilisation balances of each product at both the EU and the Member State levels must hold and take into account the international trade and other commitments of the EU.

The AGMEMOD modelling system does not distinguish between intra-EU and extra-EU trade at the Member State level (it is a non-spatial model), thus intra-EU trade disappears at the EU level when summing over all Member State supply and use identities. This implies that the EU net export variable is used as the closure variable at the EU level. Thus, the AGMEMOD 2020 combined model generates 
market supply, use and price projections under the Baseline and alternative scenario policy assumptions for both the EU27 and individual Member States, under the assumption of exogenous world prices. The assumption of exogenous world prices is an important limitation of the AGMEMOD modelling system that is being addressed in ongoing research..

The importance of incorporating CAP instruments in a harmonized way across the individual country models is a central analytical advantage of the AGMEMOD 2020 combined model. The policy harmonization approach adopted ensures that the AGMEMOD Partnership's analysis (AGMEMOD Partnership, 2008) of the differential impact across the Member States of a common policy changes reflects the likely differential impact of the analysed policy change across Member States rather than differences in how a common policy is modelled within the individual country models. The implementation of policy harmonization approach involves two steps:

1. Development of specific harmonized country policy data sets:

- Policy information which incorporates data on all current or past types of CAP direct payments;

- Consistent country datasets which, in a coherent manner, incorporate total budgetary envelopes per Member State, different types of the EU CAP direct support elements and their allocation from the total budgetary envelopes.

2. Inclusion of policy data in a harmonized way within the AGMEMOD 2020 combined model. This step involves the development of a:

- Set of equations of budgetary envelopes and payments, which are uniform for all Member States and centrally done within the combined model environment;

- Set of country specific equations, which generate policy variables reflecting the influence of policy instruments on expected gross returns for crops. For livestock and livestock products the variables generated are used to create (when combined with market prices) reaction prices.

Policy variables are then used in the supply side of each of the AGMEMOD country models in order to capture the impact of policy measures on the supply of agricultural products.

With the use of the policy harmonization approach, the AGMEMOD modelling system accounts for the vast majority of the budgetary resources utilised within the current CAP Pillar I budget measures. Three types of direct support schemes are currently supported by the CAP Pillar I budget. These payments (coupled and decoupled), are associated with the single payment system (SPS) that operates in all old Member States (EU15), Slovenia and Malta, the simplified area payments scheme (SAPS) that operates in all bar two of the new Member States (EU12), and a limited number of other coupled direct payments.

Total funding for the SPS and the SAPS and most coupled payments, is aggregated in national envelopes or national ceilings. Together these payments accounted for almost $97 \%$ of total CAP direct support expenditure in 2007. According to Council Regulation 1782/03 (2003), there are still some other aid schemes that together account for approximately $3 \%$ of CAP direct support expenditure in 2007, which are not included in the national budgetary ceilings. Only coupled payments which are defined on the basis of partial implementation of decoupling or the "optional exclusions" of SPS (Council Regulation 1782/03, Title III, Chapter 5; 2003) are included in national envelopes defined by Council Regulation 1782/03 (2003).

The allocation method utilised in the AGMEMOD policy harmonization approach ensures that the ceilings (and sub-ceilings) set out in the EU regulations (Council Regulation 1782/03, 2003; Council Regulation 73/09, 2009) are respected, that the allocation of overall national ceilings in each Member State across the three categories of coupled, historical and regional payments is correctly reflected, and that the impact of the modulated funds and their transfer from CAP Pillar I to Pillar II is incorporated appropriately.

The main assumption regarding the modelling of the impact of the different types of budgetary support is that all direct income support measures, coupled or decoupled, provide incentives to produce, and that the degree to which different types of CAP instruments (for example coupled versus decoupled) 
differ in their impact on production decisions is captured explicitly in the value of coefficients, termed multipliers. It is assumed that support related to a product or production factor associated with a particular product has a direct impact on production. Support granted to land, irrespective of the type of product produced, can also act as a production inducing factor. The magnitude of the multipliers used to determine the differential supply inducing impact of different direct payment instruments is based on both qualitative and quantitative analysis (inter alia cost-revenue calculations for individual commodity markets and assessments of the mobility of production factors in individual Member States).

Direct payments in the AGMEMOD modelling system are incorporated as policy price add-ons to the relevant producer price to form a reaction price (livestock, livestock products) or expected gross returns (crops). These policy based price and gross market return add-ons are used in the impact assessment of total budgetary support on agricultural production. The reaction price accounts for the effect of decoupled direct payments through the application of multipliers which adjust the share of budgetary support in the reaction price of livestock products and in gross return per hectare for crop products.

The multipliers are applied as production impact coefficients to different types of direct payments and for different commodities and vary significantly across AGMEMOD country models and commodities. The multipliers applied to decoupled regional or historical payments are in the range of:

$0<\left(\mathrm{P}_{\mathrm{i}_{\_} H P M} ; \mathrm{P}_{\mathrm{i} \_\mathrm{RPM}}\right)<1$,

where: $\mathrm{P}_{\mathrm{i}_{-} \mathrm{HPM}}-$ multiplier of historical payments for product $\mathrm{i}$,

$\mathrm{P}_{\mathrm{i}_{\perp} R P M}-$ multiplier of regional payments for product $\mathrm{i}$ :

The value of the historical multiplier $\left(\mathrm{P}_{\mathrm{i}_{\_} \text {HPM }}\right)$ is set lower than the value of the regional multiplier $\left(\mathrm{P}_{\mathrm{i} \_\mathrm{RPM}}\right)$. Namely, the historical payment provides a greater production incentive than the regional payment since the appropriate production technologies have already been established on farms. For historical payments the value of multipliers ranges between 0.3 and 0.6 and for regional payments between 0.1 and 0.5. The multipliers for coupled measures are valued between 0.5 and 1.0. Fully coupled payment has a multiplier set to 1.0.

Model response is crucially dependent on supply and demand own price elasticities. Their initial values are predominantly econometrically estimated and refined in the process of validation and sensitivity analysis applying common economic and agronomic reasoning. Their short-run values are rather conservative. For the most Member States and commodity markets the values of supply own price elasticities are in the range from 0.05 to 0.2 .

\subsection{Analysed policy scenarios}

Based on the recent public debate of the long-term CAP and EU budget issues (Baldock et al., 2010; The Common Agricultural ..., 2010), Baseline and alternative policy scenarios are formulated. The alternative scenario is used to analyse market impacts of a comprehensive long-term reform of the direct payments policy, captured by the introduction of EU wide flat rate area payment (EUWFAP).

\section{Baseline Scenario}

The Baseline policy scenario assumes a continuation of current policy and confines itself to the mandatory elements of the agreed CAP reforms under the Health Check. These elements are milk quota abolition after 2015 with the agreed annual increases in milk quota beginning in 2009, the abolition of set aside, the decoupling of certain direct payments and an increase in the basic modulation rate to $14 \%$ by 2012 . The additional modulated funds are used to fund CAP Pillar II measures and thus in effect reduce the national ceilings.

\section{European Wide Flat Area Payments Scenario (EUWFAP)}

The implementation of the policy harmonization methodology within the AGMEMOD 2020 combined model allows for the transparent and homogenous implementation of the proposed policy change scenario across the various Member State models. Individual country (Member State) models together form the AGMEMOD 2020 combined model. The impact of the policy changes analysed, as reflected 
in the policy data used, is inferred as the difference between the AGMEMOD model's projections under the alternative scenario and the Baseline scenario.

In the European Wide Flat Area Payments Scenario (EUWFAP Scenario) we analyse the impact of introducing a common single area payment across the EU gradually from 2014 to 2020. In form and definition it is similar to the proposals for a basic contractual payment scheme (similar to suggestions by Bureau and Mahé, 2008; Baldock et al., 2010). The EUWFAP is set at 100 euros per hectare as final value in 2020 with eligible area set equal to the agricultural area on which entitlements under the single farm payment system were established. Under the EUWFAP scenario the modulation rate is set to zero.

Both, the Baseline and the EUWFAP scenarios use the same assumptions concerning the development of exogenous macroeconomic data over the course of the projection period. In addition, given that the AGMEMOD 2020 combined model is a partial equilibrium model of EU agriculture, world prices of agricultural commodities are exogenous and are thus the same in the Baseline and EUWFAP scenario. The Baseline makes no assumptions regarding the outcome of the stalled WTO Doha Development Round negotiations (WTO, 2008). Under the both analysed scenarios, the EU agricultural trade policy for the period to 2020 is defined according to the Uruguay Round Agreement on Agriculture.

The introduction of EUWFAP scenario has important consequences for the distribution of budgetary funds between Member States compared to the Baseline scenario. The introduction of a flat area payment at 100 EUR per hectare would lead to a 39\% reduction in the total EU27 expenditure on agricultural income supports compared to Baseline scenario for the period 2014-2020 and a 54\% reduction in the final year of implementation.

Member States with more intensive agriculture would on average face larger relative declines of total budgetary support under the EUWFAP, for example with a 100 EUR per hectare flat area payment, the level of budgetary support in Greece would drop by over 85\%. Latvia is the only Member State with an estimated increase in EU budgetary support (+19\%) compared to the Baseline scenario.

Table 3: Budgetary distribution per Member States for Baseline and alternative policy EUWFAP scenario in year 2020

\begin{tabular}{|c|c|c|c|}
\hline \multirow{2}{*}{ Member State } & \multicolumn{2}{|c|}{ Direct payments national envelope } & \multirow{2}{*}{$\begin{array}{c}\text { Change in national } \\
\text { envelope }\end{array}$} \\
\hline & $\begin{array}{c}\text { Baseline Scenario } \\
(\text { Mio. EUR })\end{array}$ & $\begin{array}{c}\text { EUWFAP Scenario } \\
(M i o . E U R)\end{array}$ & \\
\hline Austria & 744,955 & 323,985 & $-56.5 \%$ \\
\hline Belgium & 648,856 & 146,619 & $-77.4 \%$ \\
\hline Bulgaria & 809,585 & 364,486 & $-55.0 \%$ \\
\hline Czech Republic & 902,222 & 356,598 & $-60.5 \%$ \\
\hline Germany & $5,774,254$ & $1,695,100$ & $-70.6 \%$ \\
\hline Denmark & $1,030,478$ & 271,676 & $-73.6 \%$ \\
\hline Estonia & 100,900 & 76,390 & $-24.3 \%$ \\
\hline Spain & $4,840,413$ & $2,538,324$ & $-47.6 \%$ \\
\hline Finland & 565,520 & 229,360 & $-59.4 \%$ \\
\hline France & $8,415,555$ & $2,958,411$ & $-64.8 \%$ \\
\hline Greece & $2,178,382$ & 325,405 & $-85.1 \%$ \\
\hline Hungary & $1,313,966$ & 582,734 & $-55.7 \%$ \\
\hline Ireland & $1,340,521$ & 430,489 & $-67.9 \%$ \\
\hline Italy & $4,184,720$ & $1,470,994$ & $-64.8 \%$ \\
\hline Latvia & 145,616 & 173,361 & $19.1 \%$ \\
\hline Lithuania & 377,360 & 279,070 & $-26.0 \%$ \\
\hline Netherlands & 853,090 & 194,669 & $-77.2 \%$ \\
\hline Poland & $3,017,407$ & $1,594,148$ & $-47.2 \%$ \\
\hline Portugal & 608,827 & 376,541 & $-38.2 \%$ \\
\hline Romania & $1,777,866$ & 988,592 & $-44.4 \%$ \\
\hline Slovakia & 386,214 & 193,928 & $-49.8 \%$ \\
\hline Slovenia & 144,110 & 49,034 & $-66.0 \%$ \\
\hline Sweden & 763,082 & 320,124 & $-58.0 \%$ \\
\hline United Kingdom & $3,975,849$ & $1,676,085$ & $-57.8 \%$ \\
\hline
\end{tabular}

Source: own calculations. 


\section{Results and Discussion}

\subsection{Market impacts of implementing the alternative policy scenario (EUWFAP)}

The analysis is focused on soft wheat, barley, maize, beef, pork and milk. Table 4 reports the main production and market impacts of introducing the EU wide flat area payment (EUWFAP) in 2020 for these commodities compared to the baseline situation.

The results are presented for the whole EU (EU27), old Member States (EU15), new Member States (EU12), as well as for two individual Member States, France (FR) and Poland (PL). France represents the group of Member States applying the historical model, while Poland represents the group of Member States applying the SAPS scheme.

The results presented below generally support the hypothesis that the redistribution of subsidies under the EUWFAP scenario does not lead to large negative changes in the level of production of agricultural commodities. However, at the EU27 level the analysed reform does lead to a significant change in the production of beef, with an estimated 3.3\% drop in the level of EU production compared to the baseline situation. Specialist EU beef production is highly dependent on subsidy support, our results suggest that decoupling those payments that under the baseline remained coupled and harmonising the per hectare level of support across EU Member States reduces the aggregate production level of beef in the EU. Given that the EU is a net importer of beef under the Baseline and that by 2020 imports still account for only a small share of total EU beef use, impact of the analysed reform on beef trade is more dramatic. Under the EUWFAP scenario EU beef net trade increases by almost $40 \%$ compared to the baseline.

For other analysed commodities no significant changes are observed. This is understandable for commodities which have never been supported by CAP direct payments, such as pig meat. Furthermore, dairy sector has mainly been in receipt of price support and even with the introduction of the dairy premium historical payment rights are less important to farm incomes in dairying when compared to beef. Thus, the limited impact of the introduction of EUWFAP on dairy is not surprising. The abolition of the EU dairy quota from 2015 (under both the baseline and EUWFAP) represents much more significant change of the policy framework than the introduction of EUWFAP. 
Table 4: AGMEMOD - Agricultural market results for EU27, EU15, EU12 and selected countries in 2020 by analysed scenarios

\begin{tabular}{|c|c|c|c|c|c|c|}
\hline & & EU27 & EU15 & EU12 & FR & PL \\
\hline \multicolumn{7}{|l|}{ Soft Wheat } \\
\hline \multirow[t]{2}{*}{ Production } & Baseline (1000 t) & 146,481 & 107,388 & 39,143 & 37,728 & 11,544 \\
\hline & EUWFAP (\% change*) & $-0.73 \%$ & $-0.81 \%$ & $-0.49 \%$ & $-1.57 \%$ & $-0.02 \%$ \\
\hline \multirow[t]{2}{*}{ Net Trade } & Baseline (1000 t) & 18,964 & 10,265 & 8,699 & 12,280 & 952 \\
\hline & EUWFAP (\% change) & $-5.53 \%$ & $-8.73 \%$ & $-1.76 \%$ & $-0.25 \%$ & $-0.32 \%$ \\
\hline \multicolumn{7}{|l|}{ Barley } \\
\hline \multirow[t]{2}{*}{ Production } & Baseline (1000 t) & 70,812 & 57,744 & 13,068 & 10,938 & 3,760 \\
\hline & EUWFAP (\% change) & $-0.79 \%$ & $-0.76 \%$ & $-0.93 \%$ & $-1.02 \%$ & $-0.32 \%$ \\
\hline \multirow[t]{2}{*}{ Net Trade } & Baseline (1000 t) & 16,503 & 15,121 & 1,382 & 6,201 & $-1,244$ \\
\hline & EUWFAP ( $\%$ change) & $-3.00 \%$ & $-3.09 \%$ & $-1.94 \%$ & $-1.81 \%$ & $0.48 \%$ \\
\hline \multicolumn{7}{|l|}{ Maize } \\
\hline \multirow[t]{2}{*}{ Production } & Baseline (1000 t) & 82,978 & 51,433 & 31,545 & 17,467 & 2,470 \\
\hline & EUWFAP (\% change) & $-1.28 \%$ & $-2.37 \%$ & $0.50 \%$ & $-1.32 \%$ & $13.64 \%$ \\
\hline \multirow[t]{2}{*}{ Net Trade } & Baseline (1000 t) & 17,995 & 8,473 & 9,522 & 11,198 & $-1,955$ \\
\hline & EUWFAP (\% change) & $-5.82 \%$ & $-14.39 \%$ & $1.81 \%$ & $-1.98 \%$ & $-3.22 \%$ \\
\hline \multicolumn{7}{|l|}{ Beef } \\
\hline \multirow[t]{2}{*}{ Production } & Baseline (1000 t) & 7,967 & 7,103 & 864 & 1,533 & 311 \\
\hline & EUWFAP ( $\%$ change) & $-3.26 \%$ & $-3.59 \%$ & $-0.58 \%$ & $-13.24 \%$ & $0.00 \%$ \\
\hline \multirow[t]{2}{*}{ Net Trade } & Baseline (1000 t) & -619 & -578 & -41 & -284 & 76 \\
\hline & EUWFAP (\% change) & $39.90 \%$ & $41.87 \%$ & $12.20 \%$ & $67.61 \%$ & $0.52 \%$ \\
\hline \multicolumn{7}{|l|}{ Pork } \\
\hline \multirow[t]{2}{*}{ Production } & Baseline (1000 t) & 20,248 & 16,511 & 3,737 & 2,188 & 2,268 \\
\hline & EUWFAP (\% change) & $0.00 \%$ & $-0.01 \%$ & $0.00 \%$ & $0.00 \%$ & $0.09 \%$ \\
\hline \multirow[t]{2}{*}{ Net Trade } & Baseline (1000 t) & $-2,762$ & $-2,331$ & -431 & -393 & 187 \\
\hline & EUWFAP (\% change) & $0.47 \%$ & $0.56 \%$ & $0.00 \%$ & $21.12 \%$ & $0.37 \%$ \\
\hline \multicolumn{7}{|l|}{ Milk } \\
\hline \multirow[t]{2}{*}{ Production } & Baseline (1000 t) & 153,809 & 125,351 & 28,458 & 26,078 & 12,506 \\
\hline & EUWFAP (\% change) & $-0.24 \%$ & $-0.33 \%$ & $0.14 \%$ & $-0.58 \%$ & $0.21 \%$ \\
\hline
\end{tabular}

* Percentage change to Baseline (Baseline $=100 \%$ ).

The results presented in Table 4 also confirm the expectation that agricultural production in the EU15 would be affected to a greater degree by the proposed change to EU direct payment policy, when compared with agricultural production in the EU12. These results are as anticipated since EU12 SAPS payments per hectare are already at a lower level that SPS payments in the EU15 and the change to the EUWFAP payment represents a small policy change relative to the Baseline for most of the new Member States. The impact of the policy change the EU15 is also ameliorated by the fact that some EU15 Member States already operate a regional payments model (Germany, parts of United Kingdom and Finland). The impact of SPS direct income support paid under the regional payments model is under the baseline lower than the impact of support that uses the historical payments model.

While the impact of the policy reform for most commodities at the aggregate EU level are not significant, there are notable differences in the magnitude of impact between Member States. The introduction of the EUWFAP has a negative production impact especially for highly supported commodities such as beef in those Member States where the historical payment system has been used.

In Member States such as France, the introduction of EUWFAP payment is expected to have have negative consequences for beef production given the use of a historical payment model, the persistence under the baseline of coupled direct payments and relatively high levels of support per hectare. In contrast production in Member States already operating the SAPS system, such as Poland, the EUWFAP reform does not represent a major change in policy since the existing policy setting is close to that which would prevail under the EUWFAP scheme. 


\subsection{Conclusions}

This paper discusses the long-term future of the CAP within the context of the EU budgetary reform process beyond 2013. One option of flatter direct payments was elaborated and their impacts on agricultural commodity markets and on the distribution of CAP Pillar I budgetary expenditure across EU Member States were analysed.

Under the EU wide flat area payment (EUWFAP) a rate of 100 EUR was used. Under the (EUWFAP) scenario the national envelope for direct payments would increase in only one Member State (Latvia), whereas all the other Member States would, in the final year 2020, lose on average more than 35\% of their support compared to the baseline situation. A different flat area payment rate could have been chosen. A higher rate would have increased the number of Member States which on a budgetary envelope basis would gain from the reform, however one of the themes of the ongoing EU budgetary review (and the CAP post 2013 reform) is a desire that the EU budgetary expenditure reflect new and emerging non-agricultural policy priorities (get reference). A flat area payment below the current EU average creates budgetary headroom under which expenditure on other policy areas can expand within the context of a fixed or only slowly growing EU budget.

Policy makers and interest groups often defend the existing direct payments system by recourse to arguments that the abolition or significant reduction of existing support would lead to large changes in EU agricultural production. Our analysis does not confirm such assertions. The production of the key European commodities, grain, livestock and dairy is not substantially reduced under the reform scenario analysed (EUWFAP). Changes are significant at the aggregate EU level for only one commodity, beef. However, more significant changes can be expected at the Member State level, as demonstrated by our analysis of the impact of the EUWFAP on French beef production.

The development and empirical evaluation of the alternative policy scenario (EUWFAP) enables discussion of other, possibly more politically significant dimensions of CAP reform. Under the EUWFAP expenditure on Pillar I of the CAP declines, such a policy change contribute to the wider process of EU budgetary reform including the abolition of the controversial British (and other) rebates. Reduced expenditure on Pillar I direct income supports could also allow an increase in the budget for policies with a more politically acceptable and less redistributive design. Such a development could be made more politically if the co-financing principle currently applied to CAP Pillar II payments was extended to the CAP Pillar I. Such co-financing could be phased in and enable the introduction of new direct payments schemes tailored to address the problem of how to differentially remunerate those who provide the public goods associated by agriculture in different EU regions. Peet (2005) argues that national co-financing of the CAP Pillar I does not have to mean the re-nationalisation of the CAP. The EU institutions could continue administering and regulating the CAP, and police nationally financed income support payments in order to prevent Single Market distortions, just as industrial subsidies are already regulated. It is worth mentioning, that the New Members States already cofinance CAP Pillar I payments under the terms of their accession agreement.

The introduction of co-financing could also help mitigating against the negative impacts of comprehensive CAP reforms at the level of individual commodities such as beef. Member States could within limits re-introduce coupled direct payment supports. However, from a longer term perspective the sustainability of maintaining individual commodities at existing production levels through the provision of budgetary support is questionable. If seemingly marginal agricultural activities are associated with significant non-commodity outputs, such as the maintenance of rural landscapes or prevention of land abandonment, such agricultural activities should be supported by measurable and directly targeted measures (Bureau and Mahé, 2008).

EU wide flat area payment (EUWFAP) could provide a solution to the inequity and competitiveness problems stemming from the existing direct payment system. However, such a straightforward yet comprehensive solution could have unwanted effects, especially on the agricultural land market (Kilian et al., 2008). Any comprehensive change to the level of budgetary inflows in different Member States is bound to provoke strong political opposition due to the path dependent character of agricultural policy payments. It is therefore likely that the payments asscoaited with the negotiated outcome to the reform will be less uniform than proposed under the EUWFAP and that additional 
corrective, so-called "objective" criteria (Copenhagen Conference discusses ..., 2010; CAP POST2013 ..., 2010; The CAP towards ..., 2010) will most be taken into account in the search for a politically acceptable solution to the problems of disparities in levels of remuneration to farmers and willingness to pay for the public goods and services provided by agriculture across EU Member States.

One of the main conclusions of our analysis is that the negative production impacts of comprehensive CAP reform cannot objectively be put forward as the main argument for hindering such reforms. Making political decisions based only on one type of possible impact would be at best insufficient. The policy makers will devote much more attention to the impact of any proposed reform on the distribution of the payments between different types of agricultural producers, commodities and regions. Any changes in the scope and distribution of CAP direct payments could have significant impacts on farm incomes and agricultural land values which could give rise to unexpected structural breaks in some regions which cannot be easily predicted.

Any comprehensive reform of the CAP should ideally be based on a thorough analysis of the wide range of impacts, i.e. it should go beyond the range of the classical agricultural sector models thar are designed predominantly to estimate market impacts of policy change. A challenge for future research is to develop policy modelling tools which can provide consistent estimates of the impacts of policy change across a more comprehensive set of indicators than is currently possible. Such indicators would include the commodity market, supply and use and agricultural price and income indicators provided by models such as the AGMEMOD model but would also include political-economy relevant indicators, as well as the indicators of important new dimensions such as provision of public goods and consequences of policy change for risk management. The question of whether such all-inclusive economic modelling tools can be developed in a real world of a given and perhaps increasing complexity remains open.

\section{Acknowledgement}

This work was supported by EU FP6 research funding, contract SSPE-CT-2005-021543, by contribution from the partner institutions throughout the EU and through the associated projects undertaken for the European Commission Institute for Prospective and Technological Studies in Seville.

The authors would like to acknowledge the work of the AGMEMOD members and affiliates in the development of the model used for this study.

\section{References}

AGMEMOD Partnership, 2008. Impact analysis of CAP reform on the main agricultural commodities. Report III. AGMEMOD - Model description. Internet, visited on September 8, 2010, http://ipts.jrc.ec.europa.eu/publications/pub.cfm?id=1577.

Baldock, D., Bureau, J.-C., Butault, J.-P., Cooper, T., Delame, N., Erjavec, E., Gohin, A., Hart, K., Heckelei, T., Kleinhan $\beta$, W., Matthews, A., Rudloff, B., Salvatici, L., Witzke, H.P., Zahrnt, V., Zintl, A., 2010. The single payment scheme after 2013: new approach-new targets. Study. European Parliament, Brussels. Internet, visited on May 25, 2010, http://www.europarl.europa.eu/activities/committees/studies/download.do?language=en $\&$ file $=312$ 08.

Begg, I., 2005. Funding the European Union. A Federal Trust Report on the European Union's Budget. The Federal Trust for Education and Research, London.

Begg, I., Heinemann, F., 2006. New budget, old dilemmas. Briefing note. Centre for European Reform, London.

Begg, I., Sapir, A., Eriksson, J., 2008. The Purse of the European Union: setting priorities for the future. Swedish Institute for European Policy Studies, Stockholm.

Buckwell, A., 2007. Next step in the CAP reform. Eurochoices 6 (2), 13-19.

Bureau, J.-C., Mahé, L.-P., 2008. CAP reform beyond 2013: An idea for a longer view. Studies and Research 64. Notre Europe, Paris.

CAP Monitor, 2009. Agra Informa Ltd, London. 
CAP POST-2013: Food production, natural resources \& 'territory' to underpin farm policy, 2010. Agra Focus 176, 8-9.

Cipriani, G., 2007. Rethinking the EU budget three unavoidable reforms. Centre for European policy studies, Brussels.

Conforti, P., 2005. The effect of direct payments of the OECD countries in world of agricultural markets. Evidence from partial and general equilibrium frameworks. FAO Commodity and trade policy research working paper No. 12. FAO, Rome.

Copenhagen Conference discusses future CAP options, 2010. Agra Focus 171, 11.

Council Regulation 1782/03, 2003. Council Regulation (EC) No 1782/2003 of 29 September 2003 establishing common rules for direct support schemes under the common agricultural policy and establishing certain support schemes for farmers and amending Regulations (EEC) No 2019/93, (EC) No 1452/2001, (EC) No 1453/2001, (EC) No 1454/2001, (EC) 1868/94, (EC) No 1251/1999, (EC) No 1254/1999, (EC) No 1673/2000, (EEC) No 2358/71 and (EC) No 2529/2001. Official Journal of the European Union, 46, L 270, 1-69.

Council Regulation 73/09, 2009. Council Regulation (EC) No 73/2009 of 19 January 2009 establishing common rules for direct support schemes for farmers under the common agricultural policy and establishing certain support schemes for farmers, amending Regulations (EC) No 1290/2005, (EC) No 247/2006, (EC) No 378/2007 and repealing Regulation (EC) No 1782/2003. Official Journal of the European Union, 52, L 30, 16-99.

Cunha, A., Swinbank, A., 2009. Exploring the determinants of CAP reform: A Delphi survey of key decision-makers. Journal of Common Market Studies 47 (2), 235-261.

Daugbjerg, C., Swinbank, A., 2007. The politics of CAP Reform: trade negotiations, institutional settings and blame avoidance. Journal of Common Market Studies 45 (1), 1-22.

Doha Development Agenda: negotiations, implementation and development, 2009. Internet, visited on February 13, 2009, http://www.wto.int/english/tratop_e/dda_e/dda_e.htm.

ECORYS, 2008. A study on EU spending. Final Report. Commissioned by the European Commission, Directorate General for Budget, Contract No. 30-CE-0121821/00-57. ECORYS Nederland BV, Rotterdam.

Frandsen, S. E., 2008. Health Check and future perspectives. Challenges for agriculture. Impacts on the commodity space and its liberalisation. XII. Congress of the European Association of Agricultural Economists - Brussels Session: "Health check and future perspectives of the CAP: Challenges for agriculture - A day of scientific dialogue", August 28, 2008, Brussels. Internet, visited on September 28, 2010, http://ec.europa.eu/agriculture/events/eaae/frandsen_en.pdf.

Garzon, I., 2006. Reforming the Common Agricultural Policy: History of a Paradigm Change. Palgrave Macmillan, Houndmills.

Grochowska, R., Kosior, K., 2008. The future of the CAP - a declining policy in the European Union? Paper prepared for the $109^{\text {th }}$ EAAE Seminar "The CAP after the Fischler reform: national implementations, impact assessment and the agenda for future reforms". November 20-21, 2008, Italy, Viterbo. Internet, visited on October 18, 2010, http://purl.umn.edu/44787.

Grybauskaité, D., 2008. Reforming the budget, changing Europe. Results of the public consultation. Plenary presentation at Budget Conference "Reforming the budget, changing Europe", Brussels, 12 November, 2008. Internet, visited on February 16, 2009, http://ec.europa.eu/budget/reform/ library/conference/intro_grybauskaite.pdf.

Hervieu, B. 2010. "Le PAC post 2013: Conférence sur le débat public. Rapport de clôture." http://ec.europa.eu/agriculture/cap-post-2013/conference/pdf/hervieu-closing-report_fr.pdf

IEEP, 2010. "Public Goods Emerging as a Central Rationale for the CAP." IEEP CAP2020 Policy Briefing. No. 7 - September 2010. . Internet, visited on October 29, 2010, http://cap2020.ieep.eu/assets/2010/9/9/Public Goods Policy Briefing.pdf.

Interinstitutional agreement between the European Parliament, the Council and the Commission on budgetary discipline and sound financial management (2006/C 139/01), 2006. Official Journal of the European Union C 139/1, 1-17.

Key, N., Roberts, M.J., 2008. Do decoupled payments stimulate production? Estimating the effect on program crop acreage using matching. Selected paper at the Annual meeting of the AAEA, 
Florida, Orlando. Internet, visited on October 14, 2010, http://purl.umn.edu/6072.

Kilian, S., Antón, J., Röder, N., Salhofer, K., 2008. Impacts of 2003 CAP reform on land prices: from theory to empirical results. Paper prepared for the $109^{\text {th }}$ EAAE Seminar "The CAP after the Fischler reform: national implementations, impact assessment and the agenda for future reforms". November 20-21, 2008, Italy, Viterbo. Internet, visited on October 18, 2010, http://purl.umn.edu/44808.

Legal texts: the WTO agreements, 2010. The Uruguay Round Final Act: full texts. Internet, visited on October 8, 2010, http://www.wto.org/english/docs_e/legal_e/final_e.htm.

Nowicki, P., Goba, V., Knierim, A., van Meijl, H., Banse, M., Delbaere, B., Helming, J., Hunke, P., Jansson, K., Jansson, T., Jones-Walters, L., Mikos,V., Sattler, C., Schlaefke, N., Terluin, I., Verhoog, D., 2009. Scenar 2020-II - Update of analysis of prospects in the Scenar 2020 Study Contract No. 30-CE-0200286/00-21. European Commission, Directorate-General Agriculture and Rural Development, Brussels. Internet, visited on May 30, 2010, http://ec.europa.eu/agriculture/analysis/external/scenar2020ii/report_en.pdf.

Matthews, A. 2010. "The CAP ost 2013: Conference on the public debate, Brussels, 19-20 July, 2010. Closing Report."

http://ec.europa.eu/agriculture/cap-post-2013/conference/pdf/matthews-closing-report_en.pdf.

OECD, 2003. Multifunctionality - towards an analytical framework. OECD, Paris.

Peet, J., 2005. The EU Budget: A way forward. Policy Brief. Centre for European Reform, London.

Public goods emerging as a central rationale for future CAP support, 2010. IEEP CAP2020 Policy Briefing, No. 7 - September 2010. Internet, visited on October 17, 2010, http://cap2020.ieep.eu/assets/2010/9/9/Public_Goods_Policy_Briefing.pdf.

Ritson, C., Harvey, D.R. (Eds.), 1997. The Common Agricultural Policy. CAB International Wallingford.

Salamon, P., Chantreuil, F., Donnellan, T., Erjavec, E., Esposti, R., Hanrahan, K., Leeuwen van, M., Bouma, F., Dol, W., Salputra, G., 2008. How to deal with the challenges of linking or large number of individual models: the case of the AGMEMOD partnership. 57(8), 373-378.

Seeder, H.-V., 2008. Agra Focus Interview with Helir-Valdor Seeder. Agra Focus 153, 7-9.

Swinnen, J.F.M. (Ed.), 2008. The perfect storm - the political economy of the Fischler reforms of the Common Agricultural Policy. Centre for European Policy Studies (CEPS), Brussels.

The CAP towards 2020: meeting the food, natural resource and territorial challenges of the future, 2010. Communication from the Commission to the Council, the European Parliament, the European Economic and Social Committee and the Committee of the Regions. European Commission, Brussels. Internet, visited on October 9, 2010, http://capreform.eu/wp-content/uploads/2010/10/communication-leak.pdf.

The Common Agricultural Policy after 2013 - public debate, 2010. Summary report. European Commission, Brussels. Internet, visited on October 15 2010, http://ec.europa.eu/agriculture/cap-post-2013/debate/report/summary-report_en.pdf.

Tracy, M., 1997. Agricultural Policy in the European Union and Other Market Economies. $2^{\text {nd }}$ Edition. Agricultural policy Studies, La Hutte.

Vrolijk, H.C.J., de Bont, C.J.A.M., Blokland, P.W., Soboh, R.A.M.E., 2010. Farm viability in the European Union; Assessment of the impact of changes in farm payments. LEI report 2010-011. LEI, The Hague. Internet, visited on June 22, 2010, http://www.lei.dlo.nl/publicaties/PDF/2010/2010-011.pdf.

WTO, 2008. "Revised draft modalities for agriculture." World Trade Organization, Committee on Agriculture Special Session, December 8 2008. TN/AG/W/4/Rev.4. http://www.wto.org/english/tratop e/agric e/agchairtxt dec08 a e.pdf

Yrjölä, T., Kola, J., 2001. Cost-benefit analysis of multifunctional agriculture in Finland. Contribution at the $77^{\text {th }}$ EAAE Seminar / NJF Seminar, Helsinki, Finland, August 17-18, 2001.

Yrjölä, T., Kola, J., 2004. Consumer preferences regarding multifunctional agriculture. International food and agribusiness management review 7 (1), 78-90. 